\title{
The use of embodied imagination and empathy to bridge actor-character dissonance
}

\author{
Èmil Haarhoff \\ Drama Department, University of Pretoria, Pretoria, South Africa, Email: emil.lehoff@gmail.com
}

\begin{abstract}
When a script stipulates actions, gestural routines and mental models for a character that clash with the personal values of the actor, it creates dissonance between what the actor (as person) believes, represents or feels, and that which the character (as fictional construct) is interpreted to represent. This dissonance may negatively impact on the believability of the actor inhabiting the 'as if' world of the character. The article proposes a theoretical approach to navigating this potentially performancerestricting dissonance through a cross-disciplinary approach that draws on embodiment, embodied imagination and empathy.
\end{abstract}

Personal restrictions, values, socialisation, culture and impulse avoidances are subjectively sculpted and embodied in and through lived experiences. In articulating the proposed approach, the article places emphasis on practically guiding and enabling the actor to manage these embodied experiences, personal values and subjective restrictions in relation to material that is perceived to be challenging and uncomfortable. This article does not aim at theorising or expanding on character development techniques, but rather to facilitate finding ways to navigate actor-character dissonance while remaining sensitive to actors and their respective processes in engaging with, and depicting, a character in a competent and believable manner. Instead of forcing actors to work through restrictions or adversely dislodging talented actors from a production due to seemingly unmanageable dissonances, this article argues for possible solutions to manage contradictory values and stances respectfully through a multi-layered process. The article will address concepts such as personal views, mental models, socialisation, will, empathy, imagination, gesture and motor intentionality.

\section{Introduction}

This article proposes a theoretical approach to navigating potentially performance-restricting dissonances between actor and character through a cross-disciplinary approach that draws on embodiment, embodied imagination and empathy. It will be argued that through training to manage motor skills, the development of embodied gestural action, the recognition of bodywisdom, the activation of an imagination/empathy model and developing reflective somatic consciousness, actors can enhance their portrayal of a character whilst bridging actorcharacter dissonance (this term will be explained later in the article). 
The lived body harbours an entire history of embodied mental models ${ }^{1}$ and gestural conditioning which is subjectively, and in some cases seemingly irrationally, bound to the individual's lived experiences. These lived experiences are further encapsulated by social and cultural paradigms. When a scripted character calls for a mental model, actions and gestural routines that clash with those of the actor, it may create dissonance between what the actor (as person) represents or stands for, and that which the character (as fictional construct) is interpreted to represent or stand for (hereafter termed actor-character dissonance). These contradictions are based on the interpretable character construct as created by the playwright/scriptwriter and revealed through the genre, character relationships and character clues in the text.

Personal boundaries, mental models and the embodiment of socialisation processes are necessary components to the longevity of the human species and the basic social functioning of the individual. These factors are personal and essential coping mechanisms that each individual constructs in order to keep safe and to successfully function within a myriad of social environments and relationships. In performance, however, these personal mechanisms may prevent the portrayal of a character that is interpreted to have a significantly different mental model or personal values than the actor has. Even though actors are aware of the fictionality of the character's behaviour, values and context (and many acting techniques assist in engaging with that fictionality), the bodily responses tied to these personal mechanisms may belie the actor's cognitive knowledge about this fictionality in performance. Thus, these personal mechanisms and their inevitable embodiment may compromise the believability and consistency of the actor inhabiting the 'as if' world of the character.

The disjuncture(s) that the article refers to do(es) not necessarily affect all actors, but this article aims at aiding those that do experience this unease and find that it restricts their ability

\footnotetext{
${ }^{1}$ A mental model is a 'dynamic symbolic representation of external objects or events on the part of some natural or artificial cognitive system' (Rickheit \& Sichelschmidt 2005, p. 9). Mental models are subjective mental representations formed though interaction with the environment, others, technology, the self and so forth. Mental models offer a predicative model for appropriate interactions and actions. Mental models consistently keep moulding through different interactions and rather edge toward optimal functioning than rationality. Furthermore, mental models are constricted through personal experiences, background, history and other related processes (Norman 2014, p. 7-8). These embodied models strongly affect reason, action and perception (Garnham 2005, p. 41).
} 
to inhabit a character. The impetus for the article stems from the author's professional experience in the performing arts over the past ten years. It should be noted that any reference to challenging and uncomfortable material, actions and their relationship to performance are thus made in the context of the author's personal, informal experiences and observations of his own and his co-performers' working processes and perceptions. There are certain characters that an actor might choose not to engage with or struggle to portray if it opposes the actor's subjective values. The scale of acceptability is defined by each actor's subjective position and personal uniqueness ${ }^{2}$.

Examples $^{3}$ of possibly challenging and uncomfortable situations and behaviours, while always based on subjective responses, may include the character Vallier's full frontal nudity bath scene in Bouchard's play Les Feluettes ${ }^{4}$ (1987), with the film version titled Lillies (1996), or the exposing sexual tension in Equus (1973) between the characters Alan and Jill. Shaffer (1982, p. 101) gives the following stage directions: 'She lifts her sweater over her head; he watches - then unzips his. They each remove their shoes, their socks, and their jeans.' In Orwell's (2016, p. 330) play 1984 (2013), the character O’Brien tortures Winston and forces his head into a cage of rats, ready to rip his face to shreds. Kane's Blasted (1995) expects actors to depict male-on-male anal rape, fellatio, urination and torture (Iball 2008, p. 3). The South African films Vaselinetjie (2017), Dis ek, Anna (2015) and Skoonheid (2011) feature scenes including aggressiveness and rape. The HBO hit television series Game of Thrones features an array of similar material and characters for actors (Dearman 2016, p. 7; Malhara 2017, p. 263). Larson's musical Rent (2008) includes potentially challenging material, such as drug abuse, anarchy, and an orgy scene in the musical number Contact. Examples of well-known characters that might trigger safeguards in some actors include Lady Macbeth in Shakespeare's Macbeth (Honigmann 2004, p. 58), the cannibalistic Hannibal Lecter in the film The Silence of the Lambs (1991) and the murderous prostitute Aileen Wuornos in the film Monster (2003). It is notable that possibly challenging material

\footnotetext{
${ }^{2}$ Personal Uniqueness (PU) indicates a "synthesis of individual talents, gifts and potentials ("U") with the personal component ("P") that facilitates its application in "appropriate" activity (assurance, persistence, etc.). The latter ("P") rarely have inborn character and are associated with an adult personality rather than the former (“U”)' (Levit 2014, p. 1).

${ }^{3}$ Please note that all examples are open to interpretation. These examples are merely to introduce the context. The depiction thereof might change from production to production.

${ }^{4}$ Note the opera version of Les Feluettes (2016) featuring the same scene.
} 
occurs across performance genres and disciplines, yet these are merely a few examples in an increasingly wide spectrum of works.

Whilst it could be argued that the fictionality of a character, the overt activation of the realm of the imagination and acting technique should be sufficient to overcome personal reservations, the author's aforementioned personal experiences in the profession demonstrated that this was often not the case. The character and context are fictitious, yet the nudity (deed, action, gesture) of the actor, for example, is not. For some, an approach to acting that focuses overtly on navigating embodied value divides between actor and character towards performance, is necessary ${ }^{5}$.

This article proposes a theoretical approach to managing such challenges related to portraying actions, gestures, patterns and mental models of a character in an embodied manner. Identifying factors that contribute to the shaping of individual protection strategies, such as mental models, core values, social norms, embodied socialisation and impulse avoidances, might aid in understanding behaviour regarding the actor-character dissonance. The concepts of embodied imagination, empathy, will and choice may act as antidotes to the bodyminded effects that anxieties, unease and restrictions could have on the portrayal of a character. This article proposes embodied, reflective and imaginative methods that can aid the management of actor-character dissonances and safely facilitate actors in their respective processes of inhabiting a character. To do so, the article will now explore how mental models are formed.

\section{Forming mental models}

Human beings are not robotic mechanisms, nor emotionless, copy and paste, plug and play objects (Fesmire 2003, p. 9; Gallager \& Zahavi 2008, p. 137; Sarte 1956, p. 326). Human beings are multi-modal, subjective and bodyminded beings (Daboo 2013, p. 183; Damasio 2010, p. 86; Wilde \& Evans 2017: 10), affected by both their internal and external environments ${ }^{6}$ as encapsulated in their embodied and lived experiences (Deleuze \& Guattari

\footnotetext{
5 The author fully acknowledges that actors have a personal choice as to whether or not to engage with a character or play.

${ }^{6}$ Lessac and Kinghorn (2014, p. 7-8) differentiate the external environment not only as the body vs. cognition, but define the external environment as everything and everyone outside of the individual (cultures, territories, energy forces, other humans etc.) that shapes and conditions thought and behaviour. They describe the inner environment as personality, cognition, body energies and unexplored internal territories.
} 
1994, p. 178; Munro, et al. 2017, p. 1; Van Manen 2016, p. xiv). In acting and performance, lived experiences, the internal and external environment, as well as the embodiment of subjectivities should be studied, expressed and managed in the service of performance-related storytelling (Ellsworth 2005, p. 16; Kemp 2012, p. xv). Unfortunately, for the purposes of performance, not all subjectivities are in service of the task at hand. The disjuncture between, and unease because of, the diverging values of the actor and that of the construct of character for one, can form obstacles hindering an actor from fully engaging in a performance. Resultantly this might diminish performance quality and possibly prevent an actor from delving into the designated character(s) or world of the play.

The character is a construct and a fictional creation by the writer, who operates within the parameters of given traits and behaviours in a network of imagined relationships under given fictional circumstances. The actor's lived experiences, though they may be different from the mental model and imagined lived experiences of the character, serve to inform the interpretation and portrayal of a character. A comprehensive understanding of the character can enable the actor to embody the character and 'simulate his or her [the character's] dilemma with eyes, bowels, heart, cognition and muscles' (Smith 2010, p. 250). Thus, acting should be embodied (Kemp 2012, p. xvi). An embodied approach to acting engages in a series of actions, gestures, patterns and reactions, interpretable as a 'state of being' (Daboo 2013, p. 180). This state of being manifests through an embodied character. A 'character is understood as the mental model of a human being in a narrated world, created by a reader from information in the text and the reader's [director's or actor's] world knowledge' (Winko (2010, p. 208). Through the combination of the text and imagination of the reader, director or actor, the character becomes a 'conceivable or possible individual entity [author's emphasis]' with interpretable modes of behaviours, personality, beliefs, intentions and wishes (Margolin 2010, p. 404) that need to be transposed from page to stage via the actor. This transposition should be believable and consistent with the fictional world of the play.

As mentioned earlier, actor-character dissonance refers to the process in which an actor, with a subjective embodied lived experience and personal values, feels uneasy about the scripted, directed or interpreted actions, gestures, personality, thoughts and mental models of a character, as these are not aligned with his/her own embodied mental model. This unease further refers to the actor's embodied apprehension of simulating or performing certain actions, patterns, gestural routines or behaviours of a character. The restriction and activation 
of such bodyminded processes, and their influence on behaviour (MacLeod et al. 2003, p. 5) stand central to this article. These four points form the basis for this article (Ellis \& Flaherty 1992, p. 2-5):

- Firstly, an acknowledgement of lived experience in order to avert focus from the preconceived surface-level and public self, and rather to focus on the multi-modal self and its myriad of subjective and emotional experiences.

- Secondly, the acknowledgement of embodiment theories and the understanding that emotional, cognitive and somatic experiences are intertwined in the stream of lived experiences and combine to contribute towards behaviour (Denzin 1989, p. 121; James 1950, p. 185).

- Thirdly, a focus on the connection of social and socio-political conventions with subjectivity and emotional experiences.

- Fourthly, a regard for emotion as a part of lived experiences, even though emotion can be regarded as messy and uncomfortable for some researchers.

Mental models are not universally absolute, but are sculpted through the subjective crystallisation of insights into lived experiences and the interactions during human life, within the individual's previous and current social and cultural contexts (Fenggang 2003, p. 199; Johnson 1993, p. 105; Rubin 2003, p. 110; Sekimoto 2012, p. 233; Vaught 2003, p. 321). The socio-cultural context often induces a guide, restricting action through the notions of consequence, reward and loss, recognition, social approval and the prospect of reducing internalised negative states, such as guilt and distress (Coeckelbergh 2007, p. 13; Dewey 1985, p. 164; Rostan 2005, p. 104). Furthermore, Noland (2009, p. 6) clearly asserts that social and 'cultural conditioning [have] been inscribed on our muscles and bones' - it is embodied. Embodied, lived experiences constitute a lived body and subjective perceptions, which constantly self-correct within their immediate environment (Carman 2005, p. 69-70; Dreyfus 2005, p. 137; Merleau-Ponty 2002, p. 292). The individual is subject to the manner in which the environment and the body steers the individual towards certain ways of acting, feeling and experiencing (Wrathall 2005, p. 122). Social identity, conditioning and habits ensure that individuals find comfort and belonging by linking individuals together and assisting them to engage with the external environment (Karsenti 1997, p. 66 in Noland 2009, p. 32; Grosz 2004, p. 4; Shusterman 2005, p. 171). 
In the context of actor-character dissonance, it might be pertinent to recognise the internal and dynamic restraining force triggered by internal and/or external conflicts. When conflict occurs, whether internal or external, personal mechanisms are activated to protect individuals and assist them to restrain from acting impulsively, or in a manner that provokes further conflict. All aspects of this process are embodied: hampering expressive possibilities, draining creative energy and negatively impacting on the believable portrayal of challenging characters and behaviours. The ability to manage these tensions is termed 'personal restraint' (Kemp 2012, p. xv). Restraint is thus the 'suppression of an event' by gaining 'executive control' over conditioned behaviour (MacLeod 2007, p. 301; 302). This manifests through the body and is involuntary, pre-reflective and precedes reason (Damasio 1999, p. 283).

It is imperative to, once again, emphasise that personal restrictions and internal and external conflicts (that stem from mental models) are embodied (MacLeod et al. 2003, p. 5, 71; Smith 1992, p. 7). The emphasis in this article is therefore on embodiment theories, from the perspective of an intelligent, lived body as the locus of bodymindedness and intrinsic body wisdom (Damasio 2010, p. 86; Lessac \& Kinghorn 2014, p. foreword) and the body as subject (Gallagher \& Zahavi 2008, p. 136-137). Embodiment is succinctly defined by Noland $(2009$, p. 8) as 'the process whereby collective behaviors and beliefs, acquired through acculturation, are rendered individual and "lived" at the level of the body'. Embodiment theories rely on the integration of the physical human body, mind, cognition, experience, gesture, emotion, thought and the concepts of reason, imagination and emotion (Bower \& Gallagher 2013, p. 111-112; Gallagher \& Zahavi 2008, p. 148; Rokotnitz 2011, p. 2). Embodiment theories do not separate the body from cognition, but celebrate their interrelationship (Bogdanov 2016, p. 135; Munro et al. 2017, p. 4; Johnson 2007, p. xii). The self and body are intimately mutual (Bosnak 2007, p. 32; Olesen 1992, p. 217) and an integral part of forming mental models. In contrast to traditional dualism (Perry \& Medina 2011, p. 62; Shusterman 2005, p. 154), the self and cognition are not disembodied, but function as an intelligent organism; the human body is 'thinkable by itself' (Merleau-Ponty 1968, p. 140). The body relates to identity (Sekimoto 2012, p. 233) and a sense of self. As Merleau-Ponty (2002, p. 277) posits: 'we merge into this body which is better informed than we are about the world, and about the motives we have and the means at our disposal for synthesizing it'. Embodied socialisation informs human behaviour, sculpting gesture and bodily techniques; thus, embodied lived experience is a subjective kinaesthetic experience (Noland 2009, p. 8). 
This demonstrates that mental models and personal values are thoroughly embodied and attempts at gaining executive control over embodiment involves the entire multimodal bodymind.

\section{Moulding mental models}

Towards facilitating the resolution of actor-character dissonance, both Fesmire (2003, p. 94) and Nussbaum (1990, p. 155) employ the metaphor of a jazz player, in whom the traditional form and training cannot be disregarded, but should be employed in order to break the rules and pertinently forge the dissonant chords and offbeat rhythms in favour of a temporarily different, but not inaccurate or distasteful sound. Nussbaum further emphasises this notion: 'The experienced navigator will sense when to follow a rule book and when to leave it aside' (Nussbaum 1990, p. 97). The purpose is to equip actors to engage with a relatively consequence free, imaginative environment in which the actor feels safe to relinquish the rule book of subjective blockages voluntarily and temporarily and indulge in 'playing some blue jazz'.

Within potentially challenging actions and character traits, Velleman (1989, p. 258) concludes that the actor might question his/her relation to such actions and ask questions, such as: 'Can I allow myself to identify with this action?' Within the context of subjectively challenging and uncomfortable material, the answer might strongly be: 'No!' An embodied sense of self and identity is imperative in the temporary deviation from personal values and stances in an imaginary context, as it secures the individual in a solid foundation, similar to a firm technique and training in music (Daboo 2007, p. 271). This notion is also important in the post-performance de-roling or de-embodiment of the character. The opposite might rupture a sense of self - neither jazz, nor music, but a cacophony. A cacophony might activate inhibiting and safeguarding functions of control that may not be necessary for the context.

Purposefully ignoring the signs communicated through the human body in order to complete an action or behaviour pattern of the character might cause anxiety, diminish competency, deviate from efficiency of function and raise a protective shield that obstructs reactions to stimuli. Moreover, scholars indicate that anxieties directly affect the imagination, motor- and action-apparatus of the body (MacLeod et al. 2003, p. 9; Schmid-Kitsikis 2013, p. 198; see 
also Freud 1993, p. 6; Freud 1926, p. 88, 94). The physical manifestation of this is physical apprehensiveness, rigidity, the arrest of motor function, tension, disavowal, bland and stereotypical characterisation and decrease in believability of a performance (Anderson 2016, p. 9; Bower \& Gallagher 2013, p. 113-117; Noland 2009, p. 4). Restraint, insecurities and avoidance impulses should not be denied, and forcing an actor to work regardless of these restrictors does not aid the product, but impedes it. These impeding structures may restrict the talented actor and influence him/her to resist attempts at characterisation, or lead the actor to exasperation and utterances such as: 'I'm just not getting it'.

Personal restrictions are always subjective. Anderson (2016, p. 9) describes subjectivity as 'Iness'. 'I' is the individual's identification with self and the subjective association with the body, habitual patterns, mental models, family, socialisation and lived experiences (Chekov 2002, p. 86). The definition of subjectivity, Bosnak (2007, p. 127) claims, might hold the key to overcoming the gap or dissonance formed through subjectivity. Bosnak defines subjectivity as 'the proprioceptive experience of identification' (ibid., p, 127). Through this definition, he claims, 'it is possible to participate in 'non-I' subjectivity through identification with an alien personage'. This can be described as a higher level 'I' with an expanded and enriched consciousness $^{7}$ (Chekov 2002, p. 87). Therefore, this article argues for the identification with contrasting mental models through the utilisation of empathy and embodied imagination.

\section{Imagination}

McLean and White (2003, p. 247) aver that Aristotle defines imagination as a state that is related to the senses and creativity in a combination of the following three characteristics:

- The imagination is a 'subject of flux of consciousness', particularly, a 'sensation of sensations' and relates to an array of impressions acquired from the senses (Smith 1984, p. 680).

\footnotetext{
${ }^{7}$ Also see Daboo (2007, p. 270) for a discussion on the self, higher-self and non-self in Buddhism and its relation to Chekhov's psychophysical approach.
} 
- The imagination is productive since it receives sensory data and actively explores, elaborates and expands these notions to their utmost creative possibilities and dialectical relations.

- Imagination is creative in the sense that it is free and unbound and in general wanders free from the constraints of any single goal, but rather harbours the goal of productive exploration and the ability to transcend.

Imagination is a bridge or transmission device between the abstract and the individual, in which the transmission between the individual and the character or world of play becomes concrete through the employment of embodied imagination (Lyons 2005, p. 56). The combination of childlike play and imagination renders characterisation as real and believable, or as Olmsted (2012, p. 78) further claims, childlike play is 'an engine that's built to run, but it won't start without an ignition. Imagination is the key'. Imagination is not the reproduction and duplication of experience, but the creative configuration of experience through cognition (Sklar 2008, p. 94).

Embodied imagination is a transformative tool (Daboo 2007, p. 268). Johnson (1993, p. 203) concurs that the self and the concept of self is not rigid and refers to this notion as 'stretching ourselves beyond our present identity' through the altering possibilities of imagination. Aristotle (Frede 1992, p. 285) further notes that imagination can be separated from the individual, whereas perception and subjectivity cannot be separated from the individual. This independence is epitomised and upheld by the dependence of the imagination on the will and is objective, in the sense that it is not necessarily affected by external stimuli. Therefore, he claims, imagination can assist the individual to transcend his/her immediate subjectivities and perceptions through consciously engaging will to deliberate, create and engage with alternatives and, as a result, (temporarily) render the impression of change and personal alterations.

It is important to note that the embodiment of a character is what Kemp (2012, p. xviii) calls a 'temporary situational self' where the actor never escapes the embodied self. Therefore the embodied self is always present in any characterisation and action. This opposes the notion that actors can conduct complete disembodiment in seeking to become a fictional character utterly and conclusively. In response to Velleman's (1989, p. 258) question regarding actor- 
character identification, Daboo (2007, p. 272) identifies it as a simultaneous 'me-and-notme'. Imagination is the 'in between' (Olmsted 2012, p. 79) that enables the actor to engage in a world of purposeful play, similar to that of childlike games, in which consequences are temporarily softened (Agosta 2014, p. 35; Bosnak 2007, p. 127). Imagination possesses the following abilities (McLean \& White 2003, p. 247):

- The ability, through the imagination, to recognise the individuality of other individuals (or constructs) and subsequently lovingly respect and acknowledge their freedom as unique and multi-modal human beings (scripted characters). Through imagining the character/other and through the actor allowing his/her mind to form the other's existence and lived experiences (scripted experiences), even playfully so, the actor necessarily acknowledges the humanity (interpretive and imaginative construct) of the character/other (Nussbaum 2001, p. 333).

- The ability to understand the meaning of imaginative images and sense data through unfolding their structures and creatively completing their embodied framework.

- The ability to explore actively and elaborate productively on the sense data through creatively engaging new and different patterns or combinations within the imagination.

\section{Empathy}

Imagination therefore enables the individual to create the abstract 'other' or character figuratively, through imaginative imagery and sensations and move towards an intentional and temporary imaginative shift (Johnson 1993, p. 10). This is encapsulated in the term 'empathy'. Empathy, for the purposes of this article, has a twofold attention (self and other) by imaginatively associating oneself with a character's scripted or interpreted situation, condition, time in history (past or future), personal values and mental model or, metaphorically, walking a mile in the shoes of another (Coplan 2011, p. 5-7; Fesmire 2003, p. 65; Hoffman 2000, p. 4; Nickerson et al. 2009, p. 43; Nussbaum 2001, p. 327-328; Johnson 1993, p. 199; Wilde \& Evans 2017, p. 5-8). Empathy, emotion and imagination are detailed by Kemp (2012, p. xiv) as utilising many of the same neural pathways as a response to both reality and fiction. According to Rostan (2005, p. 108), empathy is thus not dependent on forceful realism or the visually obvious and can be produced through identification with a fictional character. Batson $(2009$, p. 7) outlines eight definitions of the term 'empathy', of 
which the fifth concept, 'Imagining How Another Is Thinking and Feeling', is especially relevant to text analysis and characterisation. This concept is built on the imaginative pursuit of empathy through the accumulation of knowledge regarding another's character, values and desires - in this context, the scripted knowledge. Emphasis is on a twofold attention, in order to establish the difference between the actor and the character, yet endorsing respectful sensitivity.

Empathy bridges unease and renders the lived body of the character/other accessible (Agosta 2014, p. 113). Wilde and Evans (2017, p. 5) concur that 'empathy is a useful tool in exploring the connection with the non-physical other that is simultaneously imaginative, embodied and cognitive. [Their] understanding of empathy is intentionally fluid, where the binary between the cognitive and corporeal breaks down and the two intertwine'. The actor moves from sympathy (emotionless observation - feeling 'for') to the embodiment of empathy (bodyminded connection - feeling 'with') through bridging actor-character unease (Slote 2007, p. 13; Wilde \& Evans 2017, p. 7). It is, therefore, imperative for the actor to understand the scripted shaping of the character's behaviour, through empathy and embodied imagination, and perceive the subjective motivations, and occasionally irrational justifications, of the character's perceived challenging and uncomfortable actions or behaviour within the character's uniquely subjective lived experiences. Empathy relates the similarities of the character/other to those of the actor and rationally places the character's scripted adversities and life experiences closer to the reality of the actor (Nussbaum 1997, p. 85). Empathy produces respect for the character (Howey 2005, p, 157) and is therefore a catalyst towards extending the comfortable self and conditioned bodymind (Wilde \& Evans 2017, p. 10). Empathy is the primary mechanism for the concepts of tolerance, acceptance, emotion and compassion (Slote 2007, p. 4). Nussbaum (1997) elaborates on compassion and empathy:

Compassion involves the recognition that another person, in some ways similar to oneself, has suffered some significant pain or misfortune in a way for which that person is not, or not fully, to blame... One thinks, 'That might have been me, and that is how I should want to be treated'...Compassion, so understood, promotes an accurate awareness of our common vulnerability. People do not fully grasp that fact until they can imagine suffering vividly to themselves, and feel pain at the imagining. (p. 90-91) 
Empathy, intertwined with compassion, is the multi-dimensional ${ }^{8}$ catalyst that bridges the gap between the actor and the character (Rostan 2005, p. 108) by establishing the notion that, in a change of circumstances and life experiences, the actor, as a vulnerable and dependant being, could be in the same scripted situation and make similar life choices as the fictional character. Owing to the understanding that individuals can depict their own lived body states, empathy orchestrates the notion that individuals can accordingly simulate the lived body states of another (Damasio 2010, p. 85). Mimicking another's gestural routines induces empathy $^{9}$ (Batson 2009, p. 10; Wilde \& Evans 2017, p. 9). Empathy is limited in the sense that it can be either too weak to motivate any action (Hoffman 2000, p. 198), or it can be so intolerable for the actor that it causes distress and a biased prominence within the actor's personal life. Hoffman's solution would be to refer back to the jazz metaphor, in which the dissonance has to be built on an understanding of musical tradition and technique, or in this case, the subjective principles supported by the actor, accompanied by a deep knowledge of self.

\section{Imagination/Empathy strategy}

The starting block for any shifting, is the notion of short/long-term goal setting and with it the ability to re-determine subjective restrictions (Bower \& Gallagher 2013, p. 113). In addition to this, Hoffman (2000, p. 239) and Lyons (2005, p. 64) introduce the crucial element of will. They insist that the individual employs will and choice in order to allow, encourage and spur the imagination on, in turn, to shape and reshape the will into cooperation, thus creating an endless spiral of aspiration and desire. Action relates to the concepts of desire and pleasure (McLean \& White 2003, p. 245); for example, the actor's desire to fulfil a task and the character's scripted desire as motivation for a certain action, gesture or mental model. It is argued that the use of empathy metaphorically bridges the gap between the actor and the character, after which the imagination acts as a transmission device in service of the scripted action, gesture or mental model. Elements such as will, choice and desire mobilise the body to embody and invest in gestural routines removed from the mental model and perceptions of

\footnotetext{
${ }^{8}$ Refer to Agosta (2014, p. 4-5) for a discussion and explanatory figure regarding the multi-dimensional nature of empathy.

${ }^{9}$ See Batson (2009, p. 4) for a discussion on empathy and gesture as depicted in his second concept of empathy: 'Adopting the Posture or Matching the Neural Responses of an Observed Other'.
} 
the actor, thus forming the metaphorical pillars of the bridge between the actor and character, ultimately allowing the imagination to unite knowledge, empathy and action (McLean \& White 2003, p. 250). Imagination can therefore implement what the individual consciously authorises (Fenggang 2003, p. 199). Based on the aforementioned, the researcher developed the following figure:

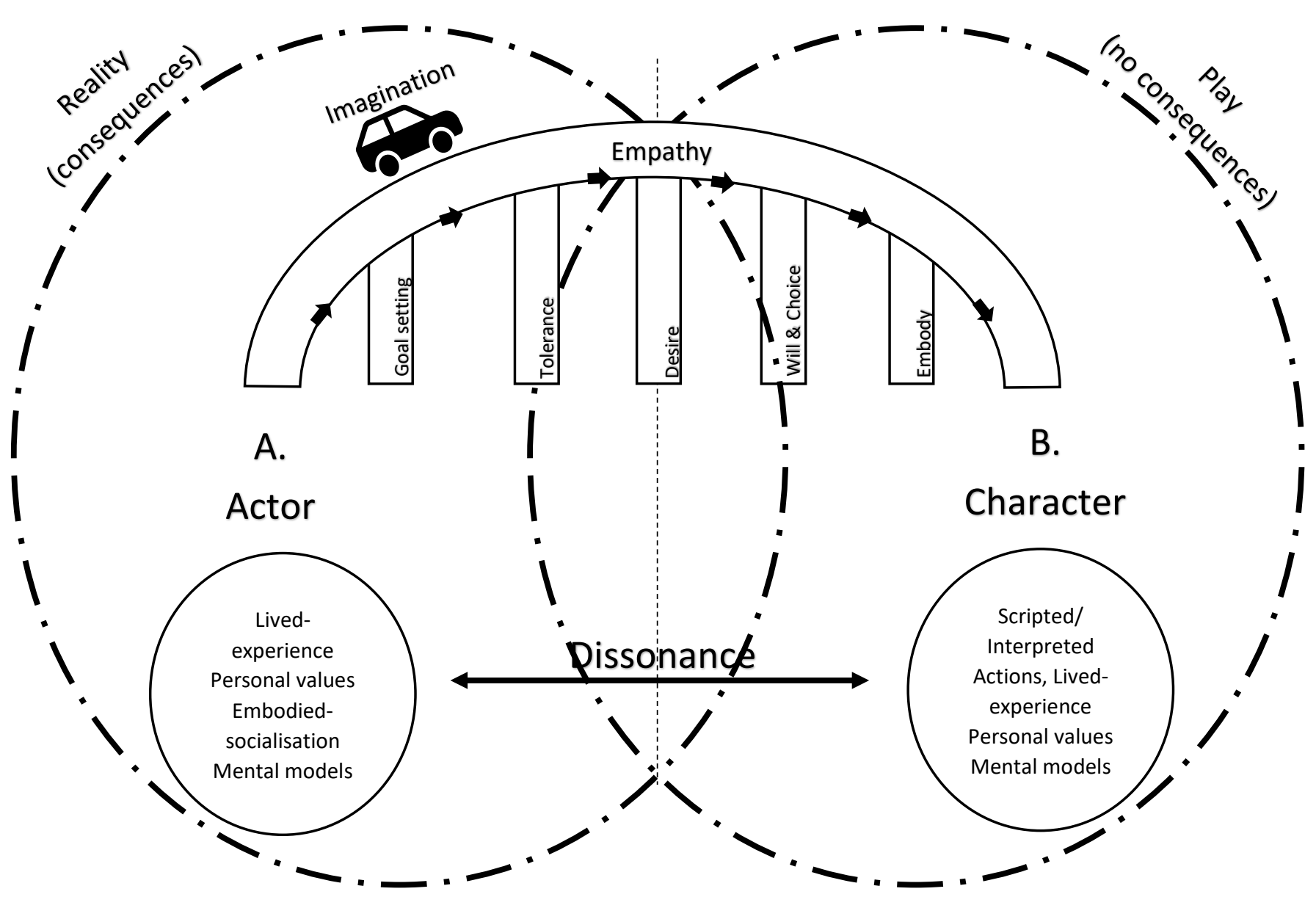

Figure 1. Imagination/Empathy strategy

\section{Embodied shifting}

Kemp (2012, p. xviii) insists that physical action, motor intentionality and muscular activity generate and stimulate imagination to a greater degree than merely utilising thought, which in turn, triggers emotion and empathy. Aristotle (McLean \& White 2003, p. 248) postulates that imagination holds a mediating position between the body and the mind, and as a holistic 
bodyminded function, reconciles freedom and creativity. This interconnected web, including the body, mind, intellect and senses, constitutes that imagination (as a sensation of sensations) is ultimately embodied in and is a congruent part of human knowledge. Subjective truth and meaning are mediated and generated through holistic embodied comprehension and the utilisation of imagination (Lakoff \& Johnson 1999, p. 6). Imagination has pertinent effects on the body and through mental imagery, merges the mind and the body to project the cognitive internal environment into that of the body and observable external environment (Bosnak 2007, p. 25; Lyons 2005, p. 19). The combination of imagination and embodied gesturing invites the notion that, as Merleau-Ponty (2002, p. 160) claims, 'to move one's body is to aim at things through it; it is to allow oneself to respond to their call'. The purpose of an embodied imagination is thus, through imagination, to shift this aim and allow the body to respond.

The proficient actor should be able, through the freedom of imagination, to sculpt sensory perception, as well as to exclude those aspects that do not serve a purpose in the current task at hand. Furthermore, the actor should be able to acknowledge how imagination illuminates and provides a tangible quality to the internal environment, and resultantly utilise this tangible quality to effect some variations in the management thereof, beyond the control of subjective mental models (Bosnak 2007, p. 25; Lyons 2005, p. 19). Equipping actors to utilise organic instruction ${ }^{10}$ in conjunction with the embodied reflective system might allow them to verify embodied concerns and re-establish aims regarding the present production. They can then self-determine the action and manifestation of an embodied restrictor through self-control methods (Hoffman et al. 2009, p. 166).

In some cases, personal restraints might exist without the conscious knowledge or understanding of the actor. Mead (1934, p. 170) insists that a lived experience that is not taken up into memory, or escapes memory through time, might be dislodged from the individual's recollection and conscious sense of self, but is never dislodged from the body on

\footnotetext{
${ }^{10}$ Organic instruction: 'The body teaching you instead of your attempting to exert control over your body. Organic instruction, then, is healthy self-teaching. It creates balance, rhythm, and inspires well-being in the body. Non-organic instructions can create conflict and confusion in your body' (Lessac \& Kinghorn 2014, p. 13). The latter description is counterproductive and might reinforce inhibition. Lessac's organic instruction can also be referred to as 'self-teaching' or 'The Teacher Within' (Munro et al. 2017, p. 4). This concept enables the actor to self-manage restrictions in conjunction with somatic reflective consciousness and kinaesthesia.
} 
a sensory and physiological experience level. Therefore, even within any number of scenes, actors might experience subjective restrictions without the recollection of a lived experience that is connected with the particular scene, but might experience reluctance and dismay on a sensory and embodied level. Wrathall (2005, p. 115) further indicates that conditioned gestural habitual patterning has the ability to impede clarity towards what caused a certain action or an avoidance thereof.

Olesen (1992, p. 216) explains that since reluctances or ailments can originate in the body without cognitive understanding, this body state can be reflected on and interpreted by the accumulation of biographical events, interactions and lived experiences. Merleau-Ponty (2002, p. 459) corroborates this statement through recognising that the individual should (through utilising 'The Teacher Within') find experiences that leave room for doubt, as well as biographical contributions that contribute to the reluctance, impulse avoidance or conflict and reflect on them. Through this process, the individual could self-determine the significance of its meaning within his/her lived experiences. With the understanding that the body is fundamental for the conscious mind (Damasio 2010, p. 26), kinaesthesia informs both conscious and unconscious behaviour (Noland 2009, p. 10). The illumination of unconscious behaviour through kinaesthesia is referred to by Saltonstall (1990, p. 15) as a 'self-soma process'. In addition, Shusterman (2005, p. 151) refers to kinaesthetic reflection as a 'reflective somatic consciousness'. Both terms encompass purposefully communicating with, reflecting on, and sensing the body (Agosta 2014, p. 112; Fontana 1987, p. 11; Van Manen 2016, p. xiv). This, Olesen (1992, p. 216) states, might awaken vulnerabilities and enforce protection strategies, or in other words, a shift-anxiety cycle.

The following process occurs on a kinaesthetic and bodily level during the embodiment pillar in Figure 1. This hypothetical strategy strengthens and enables the imagination/empathy model. Hypothetically, the process would entail a shift from the actor's personal values and gestural conditioning as encapsulated in the lived body. Any amount of 'otherness' or 'non-I' due to imagination, bodily modifications or altered gestural routines, results in a lack of bodily integrity or a lack of ownership of one's own bodymind (Sekimoto 2012, p. 234). Any amount of shifting results in anxieties, discomfort, vulnerability and uncertainty (Anderson 2016, p. 3; McCarthy 1984, p. 117). Shifting depletes and re-allocates energy from the body to the alarm-triggering entities of anxiety and 'unpleasure' (Schneide 2013, p. 219). This results in the prohibition of self-disclosure through movement and gesturing, the arrest of 
motor function and other deficiencies, as discussed earlier in this article (Noland 2009, p. 214; Todd 1937, p. 40). Anxieties and 'unpleasure' necessarily manifest in the body through gestural indications (Bodganov 2016, p. 162; Bower \& Gallagher 2013, p. 113-117; Kemp 2012, p. xv; Noland 2009, p. 9; Van Manen 2016, p. xiv). According to Damasio (2010, p. 88 ), 'the world of emotions is largely one of actions carried out in our bodies, from facial expressions and postures to changes in viscera and internal milieu'.

Through kinaesthesia the actor can consciously reflect, pre-verbally, on the meaningful manifestation of embodied anxieties (Merleau-Ponty 1964b, p. 47, 67; Shusterman 2005, p. 151; Sklar 2008, p. 94; Whitmore 1994, p. 4). The facilitator can observe the gestural manifestation as if it were an intelligible and meaningful language (Gallagher \& Zahavi 2008, p. 148). Through linguistic reflection, the actor can project subjective reflections into the external and social environment (Clark 2006, p. 372; Coeckelergh 2007, p. 16; Ellis \& Bochner 1992, p. 80; Scarry 1985, p. 11). Through motor intentionality and sensory awareness, the actor can edge towards gestural alterations and motivate further shifts through the body (Carman 2005, p. 70; Noland 2009, p. 3; Taylor 2005, p. 32). The force ensuring that this does not relapse into an endless shift-anxiety cycle, is the concept of will and choice (Hoffman 2000, p. 239; Lyons 2005, p. 64; McLean \& White 2003, p. 254). Through antidotes, such as Lessac's NRGs (Neurological Regenerative Growth) ${ }^{11}$, pain relievers, pleasure smelling and relaxer-energisers, motor arrest, anxieties and other poisons can be eased and managed to ensure the reallocation of energy back into the motor devices of the body (Lessac \& Kinghorn 2014, p. 18-34; Munro et al. 2017, p. 5-7). From here, and through the repetition of this hypothetical strategy, the imagination, purposeful play and the embodiment of possibly challenging characters might be initiated, managed and enjoyed. The researcher designed the following flow chart (Figure 2) to explain this hypothetical strategy visually:

\footnotetext{
11 'The bodymind has intrinsic means by which it deals with pain and stress, and that those means can inform behavior and movement' (Munro et al. 2017, p. 7). Relaxer-energisers include: 'Yawning, floating, shaking, humming, sighing, smiling, singing, laughing, dancing' etc. (Lessac \& Kinghorn 2014, p. 34).
} 


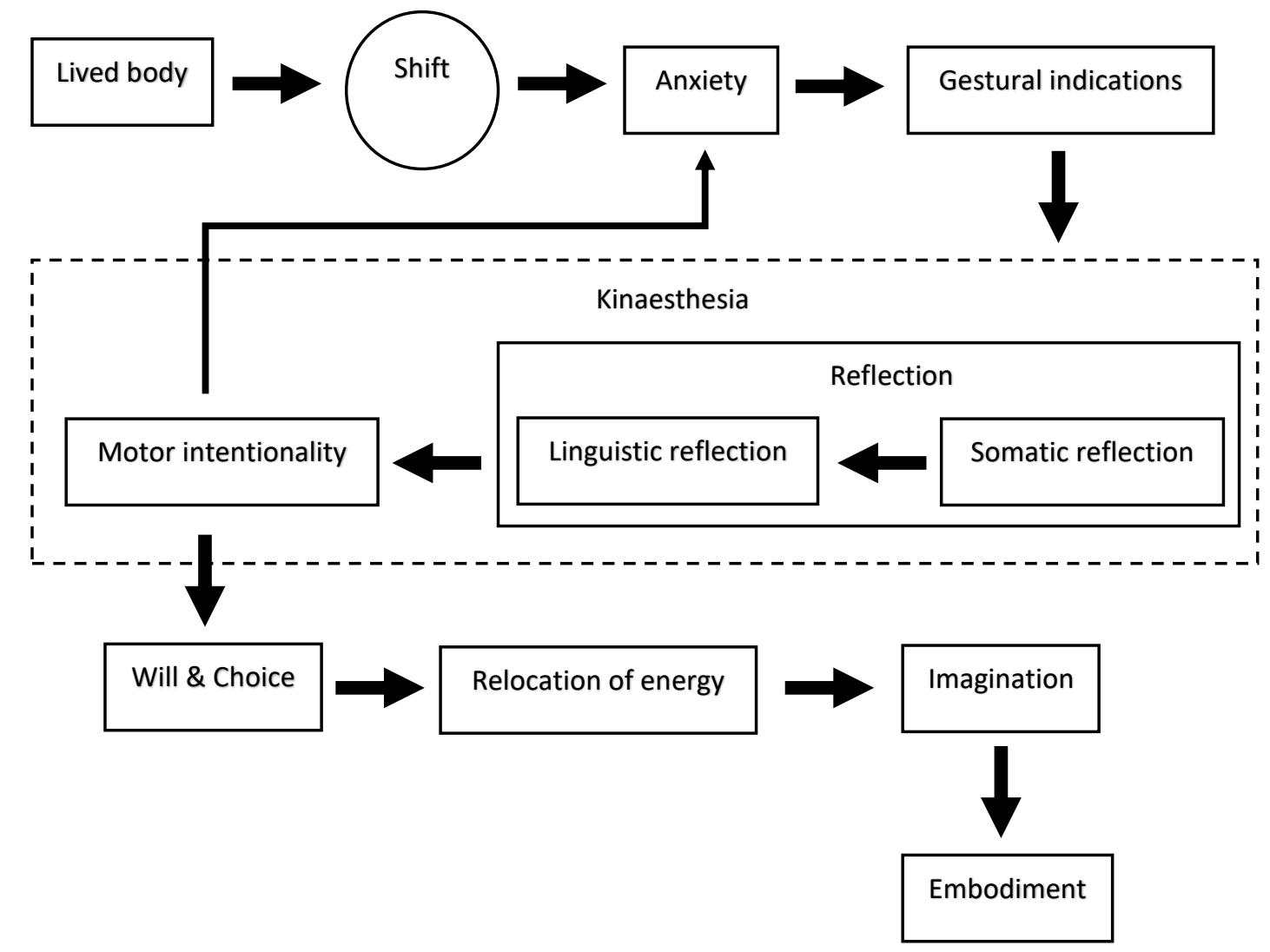

Figure 2. Embodied shifting

\section{Conclusion}

The embodiment of imagination is crucial in order to create resonance and harmony within the individual during the performance of possibly challenging scenes. Embodied imagination requires intentional communication with the individual's bodymind in order to move beyond the habitual patterning instilled by the embodiment of lived experiences, socialisation, and personal values. This is to achieve fluidity within the unknown territories of perceived challenging and uncomfortable scripted actions, gestures and mental models. Empathy is the catalyst, bridging the potentially performance-restricting actor-character dissonance and respectfully associating with the interpreted mental model of the character. Will and choice mobilise actors to transmit themselves wilfully and desirably through embodied imagination, into the relatively consequence-free world of childlike play.

Whether personal restraints and avoidance impulses arise consciously or subconsciously, the management thereof is in service of the performance product. The argument within this article is thus, that a myriad of professional acting disciplines, tools and training strategies 
might flounder in cases where competency is negatively affected by actor-character dissonances. Instead of avoiding roles that may be perceived as challenging or uncomfortable, or pushing through primal protective strategies raised through dissonance, the actor should be equipped to gain executive control, activate personal restraints and lower the performance-restricting protective shield temporarily, without relinquishing any sense of control. Through training to manage motor skills, the development of embodied gestural action sensitive to the inner environment, the recognition of body-wisdom, and the comprehension of an imagination/empathy model, actors can gain control over this multimodal bodiedness and being. Furthermore, through acquiring the skills to recognise the embodied manifestation of anxieties, the actor can employ reflective somatic consciousness in order to self-manage embodied restrictions. Finally, through engaging the will and choice, the actor might emerge from the shift-anxiety cycle and ultimately and joyfully engage in 'playing some blue jazz'.

\section{References}

Agosta, L., 2014. A Rumor of Empathy: Rewriting Empathy in the Context of Philosophy. New York: Palgrave Macmillan.

Anderson, M. K., 2016. The Wisdom of Lived Experience: Views from Psychoanalysis, Neuroscience, Philosophy, and Metaphysics. London: Karnac Books Ltd.

Batson, D., 2009. These Things Called Empathy: Eight Related but Distinct Phenomena. In: J. Decety \& W. Ickes, eds. The Social Neuroscience of Empathy. Cambridge: The MIT Press, pp. 3-16.

Bogdanov, A., 2016. The Philosophy of Living Experience: Popular Outlines (Historical Materialism Book Series / Bogdanov Library). Leiden, Netherlands: Brill.

Bosnak, R., 2007. Embodiment: Creative Imagination in Medicine, Art and Travel. New York: Routledge.

Bower, M. \& Gallagher, S., 2013. Bodily affects as prenoetic elements in enactive perception. Phenomenology and Mind, 4(1), pp. 78-93.

Carman, T., 2005. Sensation, Judgment, and the Phenomenal Field. In: T. Carman \& M. B. Hansen, eds. The Cambridge Companion to Merleau-Ponty. Cambridge: Cambridge University Press, pp. 50-73.

Chekhov, M., 2002. To the Actor on the Technique of Acting. London: Routledge.

Clark, A., 2006. Language, embodiment, and the cognitive niche. Trends in cognitive sciences, 10(8), pp. 370374.

Coeckelbergh, M., 2007. Imagination and Principles: An Essay on the Role of Imagination in Moral Reasoning. New York: Palgrave MacMillan.

Coplan, A., 2011. Understanding empathy: Its features and effects. In:. In: A. Coplan \& P. Goldie, eds. Empathy: Philosophical and Psychological Perspectives. Oxford: Oxford University Press, pp. 3-18.

Daboo, J., 2007. Michael Chekhov and the embodied imagination: Higher self and non-self. Studies in Theatre and Performance, 27(3), pp. 261-304.

Daboo, J., 2013. Stanislavsky and the Psycophyical in Western Acting. In: P. B. Zarrilli, J. Daboo \& R. Loukes, eds. Acting: Psychophysical Phenomenon and Process. Hampshire: Palgrave Macmillan, pp. 158-193.

Damasio, A., 1999. The Feeling of What Happens: Body and. Emotion in the Making of Consciousness. New York: Harcourt Brace.

Damasio, A., 2010. Self comes to mind: constructing the conscious brain. New York: Pantheon Books.

Dearman, A. J., 2016. Redefining Masculinity through Disability in HBO's Game of Thrones. Thesis. Cedar City:

Southern Utah University.

Deleuze, G. \& Guattari, F., 1994. What Is Philosophy? Trans. Tomlinson, H. \& Burchell, G. New York: Columbia University Press. 
Denzin, N. K., 1989. Interpretive Interactionism. Newbury Park, CA: Sage Publications.

Dewey, J., 1983. Human Nature and Conduct. In: J. A. Boydston, ed. The Middle Works 1899-1924. Carbondale and Edwardsville: Southern Illinois University Press.

Dewey, J., 1985. Ethics . In: J. A. Boydston, ed. The Later Works 1925-1953. Carbondale and Edwardsville: Southern Illinois University Press.

Dis ek, Anna. 2015. [Film] Directed by Sara Blecher. South Africa: Palama Productions.

Dreyfus, H. L., 2005. Merleau-Ponty and Recent Cognitive Science. In: T. Carman \& M. B. Hansen, eds. The Cambridge Companion to Merleau-Ponty. Cambridge: Cambridge University Press, pp. 129-150.

Ellis, C. \& Bochner, A. P., 1992. Telling and Performing Personal Stories: The Constraints of Choice in Abortion. In: C. Ellis \& M. G. Flaherty, eds. Investigating Subjectivity: Research on Lived Experience. Newbury Park: Sage Publications, pp. 79-101.

Ellis, C. \& Flaherty, M. G., 1992. An Agenda for the Interpretation of Lived Experience. In: C. Ellis \& M. G. Flaherty, eds. Investigating Subjectivity: Research on Lived Experience. Newbury Park: Sage Publications. Ellsworth, E., 2005. Places of learning: Media, architecture, pedagogy. New York: Routledge.

Fenggang, Y., 2003. The Decline and Reconstruction of Morality in Chinese Society. In: G. F. McLean \& J. K. White, eds. Moral Imagination and Character Development: Imagination in Religion and Social Life.

Washington, D.C: The Council For Research in Values and Philosophy, pp. 197-216.

Fesmire, S., 2003. John Dewey and Moral Imagination. Bloomington/Indianapolis: Indiana University Press. Fontana, A., 1987. Introduction: Existential Sociology and the Self. In: J. A. Kotarba \& A. Fontana, eds. The Existential Selfin Society. Chicago: University of Chicago Press, pp. 3-17.

Fontana, A., 1987. Introduction: Existential Sociology and the Self.. In: J. A. Kotarba \& A. Fontana, eds. The Existential Selfin Society. Chicago: University of Chicago Press, pp. 3-17.

Frede, D., 1992. The Cognitive Role of Phantasia in Aristotle. In: M. C. Nussbaum \& A. O. Rorty, eds. Essays on Aristotle's De Anima. Oxford: Oxford University Press.

Freud, A., 1993. The Ego and the Mechanisms of Defence. Trans. Baines, C. London: Karnac Books.

Freud, S., 1926. Inhibitions, Symptoms and Anxiety. London: Hogarth.

Gallagher, S. \& Zahavi, D., 2008. The Phenomenological Mind: An Introduction to Philosophy of Mind and Cognitive Science. New York: Routledge.

Garnham, A., 2005. What's in a Mental Model?. In: G. Rickheit \& C. Habel, eds. Mental Models in Discourse Processing and Reasoning. Amsterdam: Elsevier, pp. 41-56.

Grosz, E., 2004. The Nick of Time: Politics, Evolution, and the Untimely. New York: Routledge.

Hoffman, M. L., 2000. Empathy and Moral Development. Cambridge: Cambridge University Press.

Hofmann, W., Friese, M. \& Strack, F., 2009. Impulse and Self-Control From a Dual-Systems Perspective.

Association for Psychological Science, 4(2), p. 162-176.

Honigmann, E. A., 2004. The Murderer as Victim. In: H. Bloom, ed. Blooms Guides: William Shakespeare's Macbeth. Broomall: Chelsea House Publishers, pp. 56-59.

Howey, B., 2005. The actor's menu: a character preparation handbook. Lakewood, CO: Compass Publishing. Iball, H., 2008. Modern Theatre Guides: Sarah Kane's Blasted. London: Continuum International Publishing Group.

James, W., 1950. The Principles of Pscyhology. New York: Dover Publications.

Johnson, M., 1993. Moral Imagination: Implications of Cognitive Science for Ethics. Chicago/London: The University of Chicago Press.

Johnson, M., 2007. The Meaning of the Body: Aesthetics of Human Understanding. Chicago: University of Chicago Press.

Karsenti, B., 1997. L'Homme total: Sociologie, anthropologie et philosophie chez Marcel Mauss. Trans. Noland, C. Paris: PUF.

Kemp, R., 2012. Embodied Acting: What Neuroscience Tells Us About Performance. Oxon: Routledge. Lakoff, G. \& Johnson, M., 1999. Philosophy in the Flesh: The Embodied Mind and its Challenge to Western Thought. New York: Basic Books.

Les Feluettes: Montréal, O. d., 2016. Les Feluettes (Lilies). Opéra de Montréal. [Online]

Available at: http://www.operademontreal.com/en/shows/les-feluettes-lilies

[Accessed 1112 2017].

Lessac, A. \& Kinghorn, D., 2014. Essential Lessac: Honoring the Familiar in Body, Mind, Spirit. Barrington: RMJ Donald.

Levit, L. Z., 2014. Personal uniqueness therapy: Living with an inner ideal. American Journal of Applied Psychology, 3(1), pp. 1-7.

Lillies. 1996. [Film] Directed by John Greyson. Canada: Triptych Media/Galafilm co-production. 
Lyons, J. D., 2005. Before Imagination: Embodied Thought from Montaigne to Rousseau. Stanford: Stanford University Press.

MacLeod, C. M., 2007. Inhibition: Elusive or illusion. In: H. L. Roediger III, Y. Dudai \& S. M. Fitzpatrick, eds. Science of Memory: Concepts. New York: Oxford University Press.

MacLeod, C. M. et al., 2003. In Opposition to Inhibition. In: B. H. Ross, ed. The Psychology of Learning and Motivation. Scarborough: University of Toronto.

Malhara, T., 2017. Conceptual Analysis Of Game Of Thrones. International Journal of Innovative Research and Advanced Studies, 4(3), pp. 263-268.

Margolin, U., 2010. From Predicates to People like Us: Kinds of Readerly Engagement with Literary Characters. In: J. Eder, F. Jannidis \& R. Schneider, eds. Characters in Fictional Worlds: Understanding Imaginary Beings in Literature, Film, and Other Media. Berlin: Walter de Gruyter GmbH \& Co, pp. 400-415.

McCarthy, E. D., 1984. Toward a Sociology of the Physical World: George Herbert Mead on Physical Objects. In: N. K. Denzin, ed. Studies in Symbolic Interaction. Greenwich, CT: JA!, pp. 105-21.

McLean, G. F. \& White, J. K., 2003. Moral Imagination and Character Development: Imagination in Religion and Social Life. Washington, D.C: The Council For Research in Values and Philosophy.

Mead, G. H., 1934. Mind, Self and Society. Chicago: University of Chicago Press.

Merleau-Ponty, M., 1964b. Signs. Trans. McCleary, R. Evanston: Northwestern University Press.

Merleau-Ponty, M., 1968. The visible and the invisible. Trans. Lingis, A. Evanston: Northwestern University Press.

Merleau-Ponty, M., 2002. Phenomenology of Perception. Trans. Smith, C. London: Routledge. Monster. 2003. [Film] Directed by Patty Jenkins. USA: Media 8 Entertainment.

Munro, M. et al., 2017. Vocal traditions: Lessac Kinesensics. Voice and Speech Review, 11(1), p. 93-105.

Nickerson, R. S., Butler, S. F. \& Carlin, M., 2009. Empathy and knowledge projection. In: J. Decety \& W. Ickes, eds. The social neuroscience of empathy. Cambridge: The MIT Press, pp. 43-56.

Noland, C., 2009. Agency and Embodiment: Performing Gestures/Producing Culture. London: Harvard University Press.

Norman, D. A., 2014. Some Observations on Mental Models. In: D. Gentner \& A. L. Stevens, eds. Mental Models. New York: Psychology Press, pp. 7-14.

Nussbaum, M. C., 1990. Love's Knowledge: Essays on Philosophy and Literature. New York: Oxford University Press.

Nussbaum, M. C., 1997. Cultivating Humanity: A Classical Defense of Reform in Liberal Education. Cambridge, MA: Harvard University Press.

Olesen, V. L., 1992. Extraordinary Events and Mundane Ailments: The Contextual Dialectics of the Embodied Self. In: C. Ellis \& M. G. Flaherty, eds. Investigating Subjectivity: Research on Lived Experience. Newbury Park: Sage Publications, pp. 205-220.

Olmsted, S., 2012. Imagine childhood: Exploring the world through nature, imagination, and play. 1st ed. Boston, Massachusetts: Roost Books.

Orwell, G., 2016. 1984. Hong Kong: Enrich Culture Group Limited.

Perry, M. \& Medina, C., 2011. Embodiment and Performance in Pedagogy Research Investigation the Possibility of the Body in Curriculum Experience. Journal of Curriculum Theorizing, 27(3), pp. 62-75.

Rent - Filmed Live on Broadway. 2008. [Film] Directed by Michael John Warren. USA: Sony Pictures Home Entertainment.

Rickheit, G. \& Sichelschmidt, L., 2005. Mental Models: Some Answers, Some Questions, Some Suggestions. In: G. Rickheit \& C. Habel, eds. Mental Models in Discourse Processing and Reasoning. Amsterdam: Elsevier, pp. 940.

Rokotnitz, N., 2011. Trusting Performance: A Cognitive Approach to Embodiment in Drama. New York: Palgrave Macmillan.

Rostan, S., 2005. Understanding Extraordinary Moral Behavior in Children and Adolescents. In: D. B. Wallace, ed. Education, Arts, and Morality: Creative Journeys. New York: Kluwer Academic Publishers, pp. 103-120.

Rubin, C. T., 2003. The Moral Imagination, Ambition, and the Education of Public Servants. In: J. F. McLean \& J.

K. White, eds. Moral Imagination and Character Development: Imagination in Religion and Social Life.

Washington, D.C: The Council For Research in Values and Philosophy, pp. 105-134.

Saltonstall, R., 1990. Being Healthy: A Social Psychological Exploration of Self, Body and Gender. Ph.D.

dissertation. San Francisco: University of California, School of Nursing, Department of Social and Behavioral Sciences.

Sartre, J. P., 1956. Being and Nothingness. Trans. Barnes, H. E. New York: Philosophical Library.

Scarry, E., 1985. The Body in Pain: The Making and Unmaking of the World. New York: Oxford University Press. 
Schmid-Kitsikis, E., 2013. Traumatic seduction and sexual inhibition. In: S. Arbiser \& J. Schneide, eds. On Freud's 'Inhibitions, Symptoms and Anxiety'. London: Karnac Books Ltd.

Schneide, J., 2013. The death of an adult child: contemporary psychoanalytic models of mourning. In: S. Arbisher \& J. Schneide, eds. On Freud's 'Inhibitions, Symptoms and Anxiety'. London: Karnac Books Ltd. Sekimoto, S., 2012. A multimodal approach to identity: theorizing the self through embodiment, spatiality, and temporality. Journal of International and Intercultural Communication, 5(3), pp. 226-243.

Shaffer, P., 1982. Equus. Harmondsworth: Penguin Books Ltd.

Shusterman, R., 2005. The Silent, Limping Body of Philosophy. In: T. Carman \& M. B. Hansen, eds. The Cambridge Companion to Merleau-Ponty. Cambridge: Cambridge University Press, pp. 151-180.

Sklar, D., 2008. Remembering kinesthesia: an inquiry into embodied cultural knowledge. In: C. Noland \& S. A. Ness, eds. Migrations of gesture. Minneapolis, MN: University of Minnesota Press, pp. 85-112.

Skoonheid. 2011. [Film] Directed by Oliver Hermanus. South Africa: Swift Productions, Équation and Moonlighting Films.

Slote, M., 2007. The ethics of care and empathy. New York: Routledge.

Smith, J. A., 1984. On the Soul. In: J. Barnes, ed. The Complete Works of Aristotle. Princeton: Princeton University Press.

Smith, M., 2010. Engaging Characters: Further Reflections. In: J. Eder, F. Jannidis \& R. Schneider, eds.

Characters in Fictional Worlds: Understanding Imaginary Beings in Literature, Film, and Other Media. Berlin: Walter de Gruyter GmbH \& Co. KG,, pp. 232-258.

Smith, R., 1992. Inhibition: History and Meaning in the Sciences of Mind and Brain. Los Angeles: University of California Press.

Taylor, C., 2005. Merleau-Ponty and the Epistemological Picture. In: T. Carman \& M. B. Hansen, eds. The Cambridge Companion to Merleau-Ponty. Cambridge: Cambridge University Press, pp. 26-50.

The Silence of the Lambs. 1991. [Film] Directed by Jonathan Demme. USA: A Strong Heart/Demme Production. Todd, M. E., 1937. The Thinking Body: A Study of the Balancing Forces of Dynamic Man. New York: Dance Horizons.

Van Manen, M., 2016. Researching Lived Experience, Second Edition: Human Science for an Action Sensitive Pedagogy. Second ed. Oxon: Routledge.

Vaselinetjie. 2017. [Film] Directed by Corne van Rooyen. South Africa: The Film Factory and Letter Day Pictures. Vaught, W., 2003. A Moral Framework for Multicultural Education in Healthcare. Theoretical Medicine, 24(4), p. 301-28.

Velleman, D., 1989. Practical Reflection. Princeton, NJ: Princeton University Press.

Whitmore, J., 1994. Directing Postmodern Theater: Shaping Signification in Performance. Ann Arbor: University of Michigan Press.

Wilde, P. \& Evans, A., 2017. Empathy at play: Embodying posthuman subjectivities in gaming.. Convergence: The International Journal of Research into New Media Technologies, 27(3), pp. 261-311.

Winko, S., 2010. On the Constitution of Characters in Poetry. In: J. Eder, F. Jannidis \& R. Schneider, eds. Characters in Fictional Worlds: Understanding Imaginary Beings in Literature, Film, and Other Media. Berlin/New York: Walter de Gruyter GmbH \& Co., pp. 208-231.

Wrathall, M. A., 2005. Motives, Reasons, and Causes. In: T. Carman \& M. B. Hansen, eds. The Cambridge Companion to Merleau-Ponty. Cambridge: Cambridge University Press, pp. 111-128. 